\title{
Chapter 4. Red and Purple-Skinned Fresh Market Potato Variety Trial, 20061
}

\section{C.M. Hutchinson and Doug Gergela ${ }^{2}$}

General Comments: A goal of the red/purple-skinned fresh market variety trial is to identify a red potato that has better quality and production characteristics than Red LaSoda or LaRouge.Identification of "specialty" potatoes that expand the marketable varieties produced in Florida is also a priority. Established varieties were included to provide a baseline for the numbered clones.

\section{Planting Information}

\begin{tabular}{|l|l|}
\hline Planting Site & PSREU - Hastings Farm, Hastings, FL \\
\hline Planting Date & January 31,2006 \\
\hline Vine Kill Date & April 28, 2006 \\
\hline Harvest Date & May 15, 2006 \\
\hline Season Length & 87 days planting to vine kill; 104 days planting to harvest \\
\hline Fertilizer Program & preplant, 100-43-86 lb/A; sidedress, 65-0-56 lb/A; (2 appl.) \\
\hline Irrigation Program & seepage \\
\hline
\end{tabular}

\section{Experimental Design}

\begin{tabular}{|l|l|}
\hline Number of Varieties & 9 (Standard: Red LaSoda) \\
\hline Number of Clones & 7 \\
\hline Within Row Spacing & 8 in $(20 \mathrm{~cm})$ \\
\hline Between Row Spacing & 40 in $(102 \mathrm{~cm})$ \\
\hline Replications & 4 \\
\hline Plot Size & $16 \mathrm{ft}(4.9 \mathrm{~m})$ \\
\hline
\end{tabular}

\section{Production Statistics}

Early Vigor Ratings 41 days after planting

Highest Total Yield Red LaSoda (431 cwt/acre or $48.3 \mathrm{MT} / \mathrm{ha}$ )

Highest Marketable Yield Red LaSoda (399 cwt/acre or $44.7 \mathrm{MT} / \mathrm{ha}$ )

Best Appearance Rating B2327-2 (6.5, fair to good)

1. This document is HS1089, one of a series of the Horticultural Sciences Department, Florida Cooperative Extension Service, Institute of Food and Agricultural Sciences, University of Florida. Original publication date June, 2007. Visit the EDIS Web Site at http://edis.ifas.ufl.edu.

2. Chad M. Hutchinson Associate Professor, Doug Gergela, Sr. Biological Scientist, Horticultural Sciences Department, Cooperative Extension Service, Institute of Food and Agricultural Sciences, University of Florida, Gainesville 32611.

The use of trade names in this publication is solely for the purpose of providing specific information. UF/IFAS does not guarantee or warranty the products named, and references to them in this publication do not signify our approval to the exclusion of other products of suitable composition. All chemicals should be used in accordance with directions on the manufacturer's label. Use pesticides safely. Read and follow directions on the manufacturer's label.

The Institute of Food and Agricultural Sciences (IFAS) is an Equal Opportunity Institution authorized to provide research, educational information and other services only to individuals and institutions that function with non-discrimination with respect to race, creed, color, religion, age, disability, sex, sexual orientation, marital status, national origin, political opinions or affiliations. U.S. Department of Agriculture, Cooperative Extension Service, University of Florida, IFAS, Florida A. \& M. University Cooperative Extension Program, and Boards of County Commissioners Cooperating. Larry Arrington, Dean 


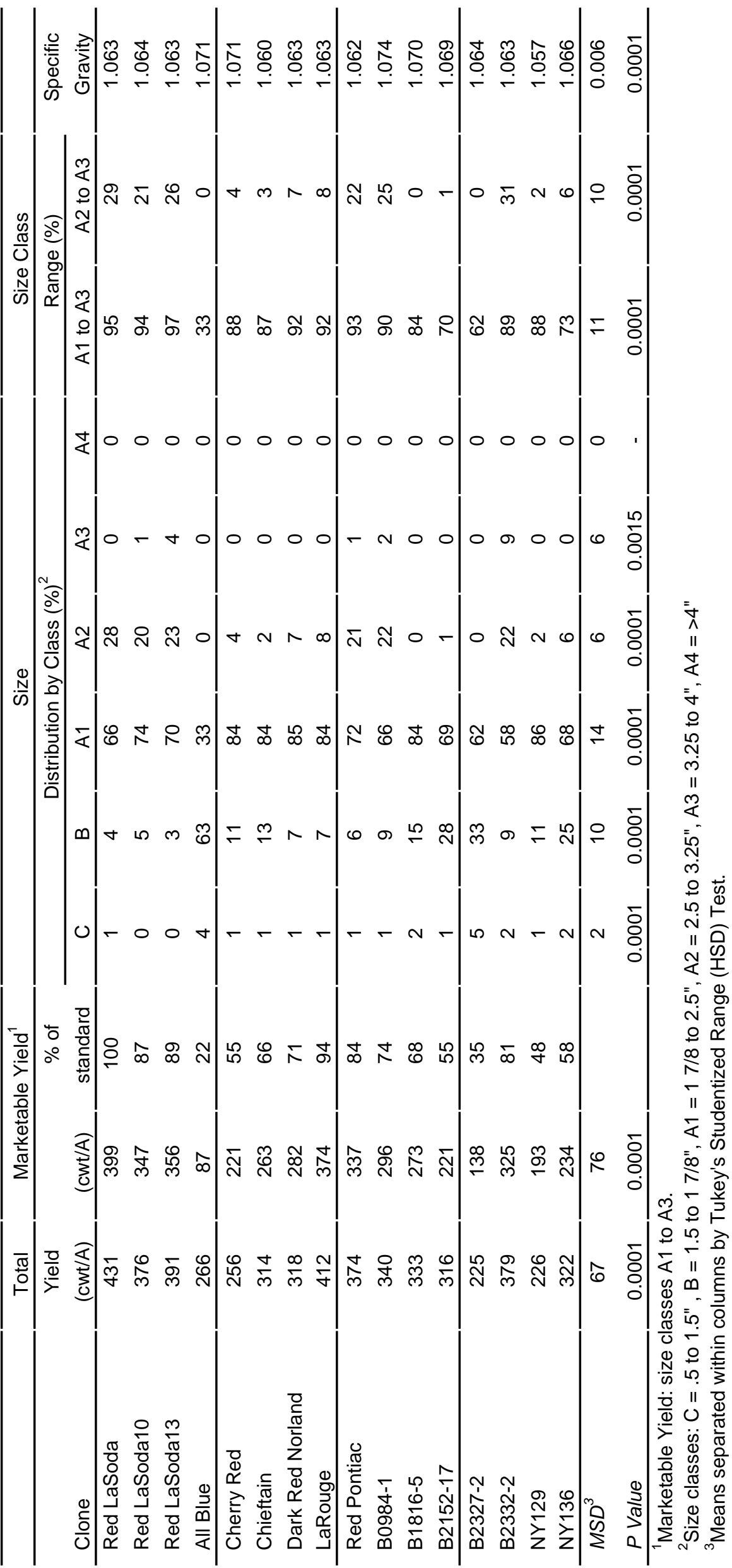




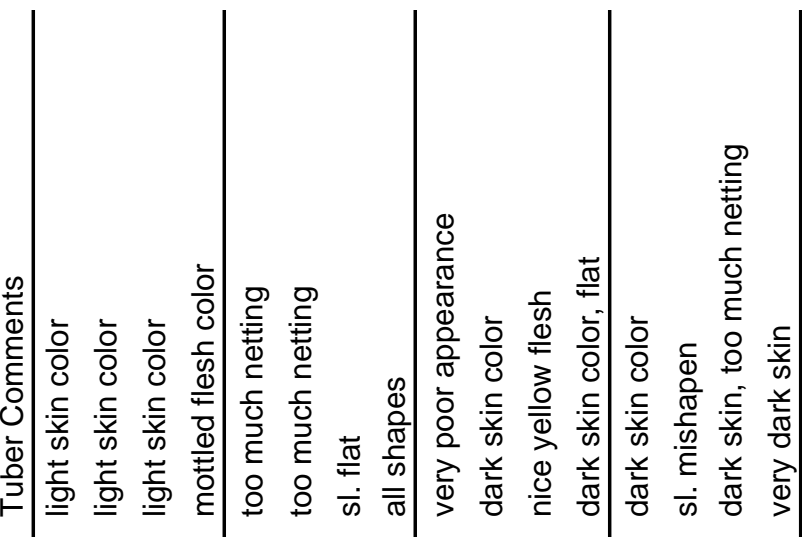




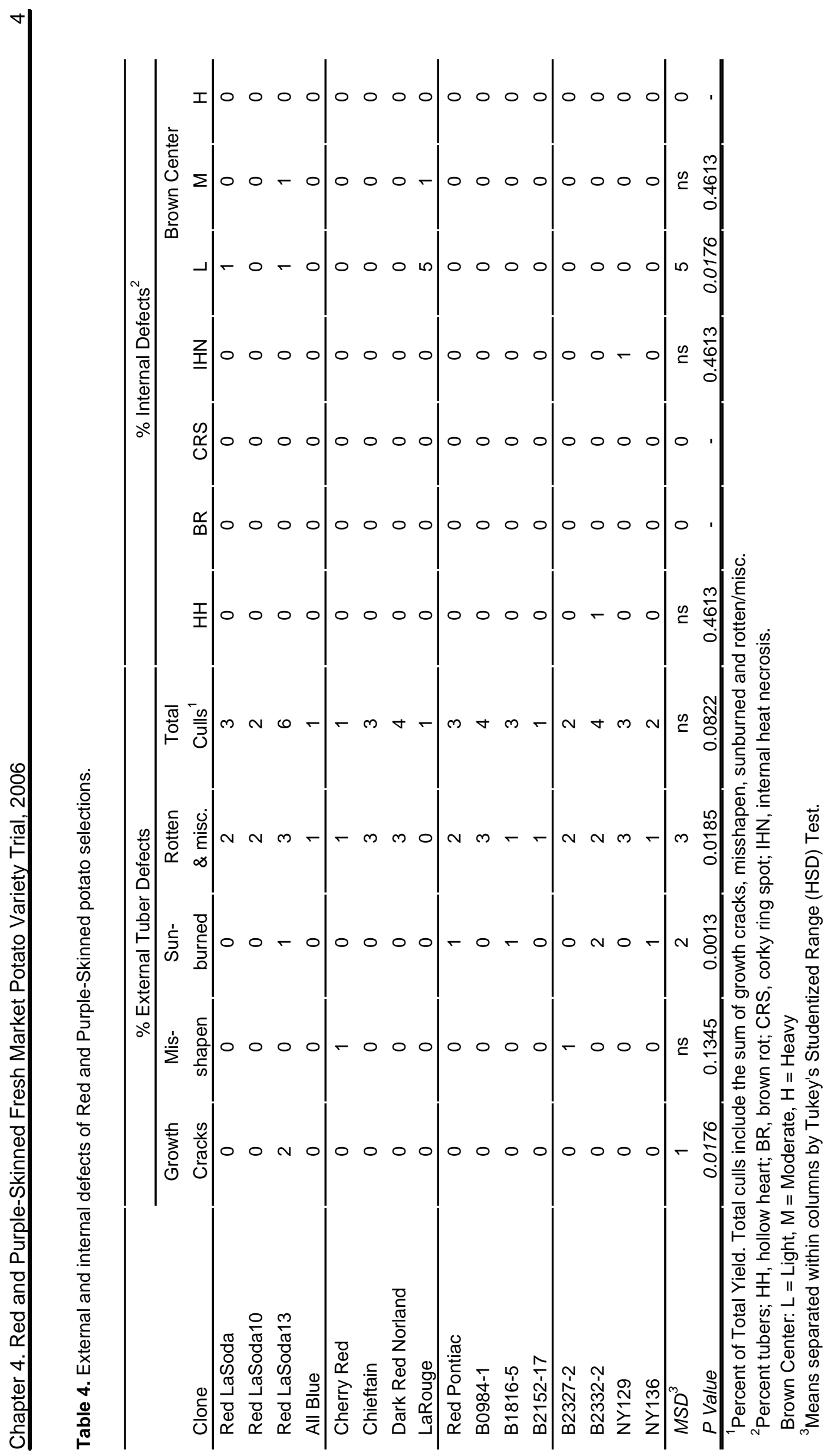

